\title{
China's Internal Security Dilemma and the "Great Western Development”: The Dynamics of Integration, Ethnic Nationalism and Terrorism in Xinjiang
}

We say China is a country vast in territory, rich in resources and large in population; as a matter of fact, it is the Han nationality whose population is large and the minority nationalities whose territory is vast and whose resources are rich. (Mao 1986, 47).

Although much water has passed under the bridge in political, economic and ideological terms since Mao Zedong's utterance, it would appear that the sentiment expressed therein retains a powerful hold over the contemporary Chinese state's approach to its geographically and culturally diverse ethnic minority populations. Most particularly, since Jiang Zemin’s launching of the Great Western Development (Xibu da kaifa) program in June 1999, Mao’s observation regarding the disposition of geography and population between China's ethnic minorities and the majority Han, has assumed a new importance. Although this campaign can be seen as "an amorphous set of diverse policy agendas and instruments not designed to form a complete and coherent programme, but rather appeal to as many interests as possible simultaneously”, it nonetheless appears to have one major guiding principle - the more thorough integration of China's predominantly ethnic minority populated "western regions" (Holbig 2004, 335-338). This paper suggests that a number of key challenges to China's security stem from its ongoing, and recently revitalised and reinforced, project to integrate the “interior” provinces in the form of the Great Western Development campaign. This campaign is not simply a regional one, but a national one with potentially international implications. As the scope and immensity of this program and the diversity of the regions encompassed by it are impossible to address in this brief discussion, the paper will focus on one region in order to illustrate the security dilemmas for the state that are stemming from its accelerated integrationist project. ${ }^{1}$ The “Xinjiang Uighur Autonomous Region” forms an instructive “test case” for the proposed argumentation and theoretical framework because it encompasses a 
broad sweep of potentialities that could challenge the state's "internal security" into the $21^{\text {st }}$ century. $^{2}$

Drawing upon some notions of "human security” from International Relations (IR) theory that will be explored and related to the Chinese context below, the paper suggests that the Chinese state can be conceived of as confronting an "internal" security dilemma in Xinjiang that is largely of its own making. Ultimately, in the context of an ethnic minority region such as Xinjiang, this security dilemma is focused on the relationship between security and identity. In particular, it is proposed that the rise of ethnic nationalism and even "terrorism” in Xinjiang has at its core an essential contestation of identities reflected in the state's discourse of development and security. As such it encompasses a disjuncture or tension between the aims and strategies of the state's developmental project, their impact on regional socio-economic conditions and the evolution of ethnic identities. Utilising the concept of the societal security dilemma this paper suggests that the actions of the Chinese state in attempting to ensure the "security" of such regions as Xinjiang are in fact generating dynamics of insecurity amongst the region's non-Han ethnic groups. Through a discussion and analysis of state policy in Xinjiang and the discourse that surrounds it, the paper proposes that the state has made a significant shift in the way it perceives the nature of its dilemma in Xinjiang and the most efficacious means to address it. Moreover, it will also be suggested that the issue of Uighur "terrorism” has effectively been "securitized" through the deployment of an ascriptive state discourse over the preceding decade that portrays the issue of Uighur separatism as intimately connected to a triumvirate of radical Islam, under-development and international "terrorism" that presents a challenge to "national unity". First, the paper begins by sketching the broad brushstrokes of the application of the theories of human security, in particular the notion of a "security dilemma" to intra-state conflict (in the case of Xinjiang inter-ethnic conflict). Subsequently, the paper identifies the ways in which such a framework 
is applicable to the case of Xinjiang, drawing on a historical analysis of Chinese policy in the region since 1949 but with particular emphasis on the 1990 to 2006 period.

\section{The Societal Security Dilemma and the Case of Xinjiang}

An under-examined facet of "security" concerns questions of identity. Adopting some notions of "human security" from IR scholarship will allow us to place the issue of identity at the core of "security" concerns. In particular, the concept of the "security dilemma”, common in IR theory, can be brought into the state to provide a framework through which to address the issue of identity in China's security concerns. The basic concept as it stands in IR theory rests upon the notion that the actions of a state to enhance its security produce reactions that can make it less secure via inducing insecurity in other states regarding its intentions in the acquisition of arms, for example. In essence the security dilemma is primarily concerned with the juxtaposition of the actors' intentions - security - and the outcome of their policies/actions - insecurity. In the IR conception of the security dilemma it is the sovereignty of the state that is the object of security, thus leading to a focus on military capabilities of states in some IR analysis of the security dilemma. But if our focus or field of inquiry is within the state, for example the Xinjiang Uighur Autonomous Region of China, the object of security changes. According to scholars such as Buzan, Roe and Waever, for example, what is at issue in security terms within the state is the concept of "societal security" (Buzan 1991, 122-23; Waever 1993, 24-25; Roe 2005). As its label suggests, societal security concerns itself with the security of collectivities or "societies". According to Waever et al, there is a distinction between state security and societal security: state security is generally conceived of as concerned with protecting the sovereignty of the state from external threats, while societal security is concerned with threats to identity. Both, however, relate to survival: if a state loses its sovereignty it will not survive as a state, while if a society loses its identity it will not survive as a society. In a world of nation-states there is generally more than one such 
collectivity or society aspiring or claiming identity as an ethnic group or nation within the territorial bounds of the state. Indeed, this is certainly the case given the great ethnic diversity of the population of contemporary China. This produces a duality whereby the state can be undermined by threats to its constituent societies, while state security can also be weakened or compromised by a high-level of societal cohesion. For example, a state’s program of "nationbuilding” or integration may come into conflict with the identity of one of its constituent societal groups. In the case of China, an increasingly Han conception of Chinese nationalism and Han-dominated state discourse, could be seen to be coming into conflict with the assertion of various ethnic minority identities. Importantly, the societal security literature suggests that when such a situation occurs it creates an excessive concern with state security a dynamic that this paper will suggest is exhibited in the actions and discourse of the contemporary Chinese state.

One of the most salient features of contemporary China that contributes significantly to this excessive concern with state security is the political, strategic and cultural significance of its diverse population. Thus, although the fifty-five officially recognised ethnic minorities constitute only eight and a half per cent of China's population according to the 2000 census, they are concentrated in $64.3 \%$ of the country's total land area and $90 \%$ of China's border regions (Zhu \& Blachford 2006, 330; Information Office of the State Council of the PRC 2005). ${ }^{3}$ The security implications of China's ethnic minorities vary due to a number of important factors such as geographic concentration and varying degrees of acculturation to the dominant Han society. In particular the fact that some are widely dispersed throughout China and others are primarily concentrated in strategic regions along China's periphery, results in differing interpretations and analyses regarding the challenges faced by the state in relation to its officially recognised ethnic minorities. From Beijing's perspective, however, the situation of the Uighur in Xinjiang presents it with a series of incomparable, potentially troublesome 
characteristics. First, the Uighur are the dominant ethnic group in Xinjiang and are primarily concentrated within the bounds of this administrative unit. Second, the Uighur are predominantly Muslim in religious confession. Third, a substantial number of Uighur currently reside in the neighbouring Central Asian republics, in particular Kazakhstan and Kyrgyzstan. Fourth, the Uighur have a recent history of separation, and some would argue even independence, from the Chinese state (Forbes 1986; Wang 1999). ${ }^{4}$ Significantly, for this discussion, Waever defines "societies” as "politically significant ethno-national and religious identities” (Waever 1993, 22), a definition into which the Uighur clearly fall. Moreover, he clearly highlights the central dilemma that such identities may pose for the state:

...societal identity is one that it is not only robust enough in construction, and comprehensive enough in its following, but also broad enough in the quality of the identity it carries, to enable it to compete with the territorial state as a political organizing principle. A societal identity is able to reproduce itself independently of the state and even in opposition to the state's organisational principle (Waever 1993, 23).

Therefore, the major issue that this perspective highlights in the Chinese context is the potential for the development of an emerging disjuncture between the interests of the state and the identity of its predominant population, the Han, and those of the officially recognised ethnic minorities. As noted above, societal security is focused on identity. Thus, an internal "security dilemma" exists when societal security, that is to say when the identity of a constituent element of a state's population is threatened. However, the question that needs to be asked, is how? According to Roe, societal security is threatened when a society believes that its "we" identity is being put in danger, whether this is objectively the case or simply perceived. He argues, that, “Those means that can threaten societal identity range from the suppression of its expression to interference with its ability to reproduce itself across generations” (Roe 2005, 48). Thus a wide range of state action may threaten the reproduction of identity; from restrictions on the use of language, dress, control or closure of places of education and worship, deportation or killing of members of the community and state-induced 
population change. This is important for a discussion of "internal security" in contemporary China as the "security dilemma”, framed by the concept of societal security suggests that security actions are always taken on behalf of, and with reference to, a particular collectivity. Moreover, the societal security literature also postulates that an issue becomes "securitized" through a discursive process on behalf of the state. This "securitization theory" argues that security issues are constructed "according to a dialectic between securitizing state agents and an accepting or rejecting public audience, mediated by a stock discourse of security characteristics such as urgency and exceptionality” (Neal 2006, 34). What is significant to take from these approaches in addressing the Chinese context is to consider a number of questions regarding "security”. First, which collectivity is the state acting to protect? Second, once that choice is made, how do the actions taken to protect the security of the state impact upon the societal security of the constituent populations of the state? Third, does the Chinese state’s actions and discourse exhibit a "securitization" dynamic whereby key issues are deemed to be defined by "urgency" and "exceptionality"? With these questions in mind, a discussion of the goals, policies and outcomes of the state's Great Western Development, with specific examples from Xinjiang, may provide some possible answers to these questions. It will emerge that the state is increasingly acting to ensure the security of the dominant societal group - the Han - and that this process, exhibited in the state's political, economic and ideological program, may be threatening the societal security of its ethnic minority populations and ultimately contribute to the development of potential internal "security dilemmas". Finally, the "stand out" issue that demonstrates the Chinese state's "securitizing" tendency is the notion of Uighur "terrorism" in Xinjiang.

\section{The Discourse of the “Great Western Development"}

It is perhaps instructive, in the context of some of the comments/observations noted above, to define where exactly this campaign is targeted. What constitutes the "West" in this 
campaign has changed on occasion since the initiation of the campaign in 1999, yet is clear that it is more than a simple geographic designation. By 2001 fourteen "western provinces and autonomous regions" were deemed to constitute the focus of the Great Western Development - the provinces of Qinghai, Gansu, Shaanxi, Sichuan, Yunnan, Guizhou, the municipality of Chongqing and the autonomous regions of Xinjiang, Tibet, Ningxia, Inner Mongolia, the Guangxi Zhuang Autonomous Region, the Xiangxi Tujia-Miao Autonomous prefecture (Hunan) and the Yanbian Korean autonomous prefecture (Jilin) (Goodman 2004, 320). As this list demonstrates, however, these regions are not exclusively "western” given that the Guangxi Zhuang autonomous region, for example, has a southern coastline. However, the majority of the regions identified are characterised by economic under-development, lack of infrastructure, large/significant numbers of ethnic minorities and are far into the interior of the landmass. As such this “west”, with Inner Mongolia encompassing much of China's northern border and Guangxi abutting the economic powerhouse of Guangdong, is thus a political, economic and even ideological designation. One observer has noted that the, "Western Development is a framework in which the discourse of historical, social, cultural and political interaction is conducted” (Sines 2002, 6).

The general tenor of this complex discourse can be characterised as simultaneously paternalistic and disdainful of the ethnic minorities, portraying the ethnic minorities as "younger brothers and sisters" that require the assistance of the more advanced (ie. modern) “elder brother” Han in order overcome their social and material backwardness (Sines 2002). This is coupled with the official and popular representations of China's ethnic minorities through tourism, films, pictorial representations etc - as primitive or exotic in contradistinction to the more reserved representation of the Han, who Gladney notes are generally portrayed in western-style, and “modest”, clothing (Gladney 2004, 51-84). The implication is clear - the ethnic minorities represent "traditional", colourful and ultimately 
"backward" societies, whereas the Han represent modernity. A recent example of such representations of the amorphous and primitive "West", in particular of Xinjiang, can be seen in Ang Lee’s film, Crouching Tiger, Hidden Dragon. In the film, Xinjiang is portrayed as a wild, desolate and remote (both geographically and culturally) frontier landscape. As a number of observers have noted regarding this representation, Xinjiang is portrayed as the frontier in perpetuity, a land of both great opportunity and great challenges (Sines 2002, 6; Tyler 2003). Thus, both the regions of the "West" and the peoples that inhabit them are portrayed as forming a duality of under-development and opportunity for the Chinese nationstate. How does this "oriental orientalism”, as Gladney would have it, correlate with the contours of the Western Development Campaign and the notions of societal security outlined above?

Perhaps most important, is that this perception of the ethnic minorities and the amorphous "west" that they inhabit is clearly informing the trajectory of the Great West Development in terms of both goals and policies. Significantly, the campaign is conceived as a state and nation-building one. The relationship between state and nation, however, under the PRC has been problematic, with the Chinese Communist Party (CCP) simultaneously embracing the discourse of the nation-state and multi-nationalism. The former emphasises the commitment to economic development and modernization, while the latter emphasises the state's intended inclusivity toward its ethnic minority population. Thus, there has been since the formation of the PRC an inherent tension, and perhaps a hidden source of potential conflict, between these two discourses:

In the view of the state, a citizen of the PRC is in some sense a national (guomin) whether they are Han or not. Necessarily the viability of this position depends on the extent to which the state-idea of the PRC is accepted in the population itself, both Han Chinese and other nationalities (minzu) (Goodman 2004, 325. My emphasis). 
This dynamic has been reflected in the practice of Chinese "minority policy" since 1949 through the contradictory establishment and maintenance of "national regional autonomy” for ethnic minorities, simultaneous with the stated goal of assimilating all ethnic groups in China (Mackerras 2004). Indeed, the “acceptance” of the state-idea of the PRC by China's ethnic minorities since 1949 has been varied, from the apparent acceptance of the Hui for example, and the periodic rejection of it by the Tibetans and Uighurs.

Yet since the launching of the Great Western Development there has been a shift of emphasis in the way in which the state's approach to ethnic minorities is framed. Nicolas Becquelin notes that the rhetoric of the Great Western Development alludes to nation-building perspectives, including, "the theme of 'manifest destiny'; the civilizing imperative; the rich resources lying untapped that 'wait' for the spiritual impulse of the 'Chinese nation' for their exploitation; and the ambition of the Chinese nation to 'stand up' in the international environment” (Becquelin 2004, 372). In particular, he cites a June 2000 article by the head of the State Ethnic Affairs Commission, Li Dezhu, as outlining the change of emphasis in regard to its approach to China’s “nationalities question”(Li 2000). Becquelin asserts that:

...this landmark article read as a programmatic document, a disclosure of the "real objectives" of the campaign to "Open up the West", as opposed to the rhetoric of "common prosperity" which had prevailed until then. But it also signalled closure: as the long-sought objective of seamless integration of minority nationalities into the "Chinese nation" draws near, history has entered an end game, and there is no necessity to proceed with caution...This shift is thus essentially a narrowing between the unstated and the stated goals of policies regarding minority nationality areas. It reflects the new-found confidence that the party-state now has sufficient control and power to take any counter-measure needed (Becquelin 2004, 374).

However, this assessment of the article may be over-stated. In particular a more careful analysis of Li's article suggests that while the state certainly perceives it to be the right historical "moment" in which to achieve the thorough integration of both the ethnic minorities and the regions they inhabit, it also recognises the challenges and obstacles that may prevent 
this development. According to Li, there are five major "aspects in handling national relations in western China":

1) Historically, national relations in western China has been a sensitive one. There are historical factors influencing national relations in these areas. 2) There is heavy religious influence in these areas, thus national relations are very complicated. 3) There are always disputes about boundaries, water, grassland, frost and minerals in these areas. There will be similar disputes in developing western China. 4) Cultural traditions and lifestyles of nationalities need to adapt to new social and economic developments. 5) Due to cultural and religious factors national relations in these areas are subject to international influences. (Li 2000)

In essence, the Great Western Development, in the state's perspective, is about overcoming these obstacles. This rationale of economic development as a cure-all in the context of China’s “nationality problem” and the precipitous historical “moment” for its implementation is also clearly expressed:

So the final solution for these problems lies in developing social productivity in areas of minority nationalities. The strategy to promote social and economic development of western China is a fundamental way to speed up the development of minority nationalities, and a necessary choice to solve China's nationality problems under new historical circumstances. (Li 2000. My emphasis)

Significantly, for the subsequent discussion of the contours of the Great Western Development in Xinjiang, Li also elucidated the state's conviction that "national unity" and “development” are inter-linked. Moreover, it also acknowledged, to a degree, that the process of accelerated economic development and integration entailed by the Great Western Development may actually exacerbate some of the factors that were identified by Li as affecting the "handling of national relations":

Implementing the Great Western Development strategy will provide the material foundation for strengthening national unity and social stability; while national unity and social stability will create a favourable environment for implementing the strategy. On the other hand, implementing the strategy may bring about new issues and problems which might challenge national unity and social stability. Implementing the strategy will lead to further opening-up. Overseas hostile forces will probably take this opportunity to penetrate China. We must be highly vigilant on this and take effective measures to safeguard national unity and social stability in order to smoothly implement the strategy ( $\mathrm{Li}$ 2000. My emphasis). 
Thus although the possibility of the Great Western Development exacerbating the situation in ethnic minority regions is acknowledged, it is conditioned by a predilection to blame external influences for complications in "national relations". Although statements such as these suggest that Becquelin has overstated the change in Chinese policy, Li's reference to the impact of the Great Western Development on the issue of population transfers, long a sensitive issue in the context of China's ethnic minority policies, does suggest a change in emphasis. ${ }^{5}$ While stating that the first two decades of "reform and opening" caused population transfers to the eastern provinces, Li notes that the Great Western Development "will bring about a population flow to the west” (Li 2000). This in itself is significant as the Chinese government throughout the 1990s denied that substantial in-migration of Han into ethnic minority regions such as Xinjiang was occurring. Interestingly, and perhaps suggestive of China's "new found confidence" in regard to ethnic minority policy, the article also acknowledges that this may cause inter-ethnic conflict:

At the same time new issues and problems may arise...It is important for the Great Western Development and national relations to handle this issue well. In keeping with the increased population flow of the various ethnic groups, there will be some changes in the proportions of the nationalities. There will also be some contradictions and friction in their contacts ( $\mathrm{Li} \mathrm{2000).}$

Li's prescription to handle this apparently inevitable side-affect of the Great Western Development consists of implementing policy in line with a series of formulas or guides that highlight the subtle change in policy:

Four principles must be upheld when making a new policy: (1) Three beneficial principles - it must be beneficial to the development of the socialist productive forces, increase of comprehensive national strength and to the improvement of people's living standard; (2) Three introducing principles - introducing talents, technology and capital; (3) Three mutual dependence - Han people can't live without the national minorities and vice versa, one national minority can't live without the others; (4) Han people and national minorities in China should learn from each other about their cultural achievements (Li 2000. My emphasis). 
Therefore, although the Great Western Development is concerned with addressing the uneven economic development of the "west”, it will do so on the basis of preserving "national unity" and "social stability" with the majority Han leading the way forward. As the subsequent discussion will suggest, however, it is the tensions and contradictions between the goals of “national unity”, "social stability” and economic development encompassed in the Great Western Development that may in fact be generating dynamics of insecurity in the context of Xinjiang.

\section{China's Program of Integration in Xinjiang and Societal Insecurity}

Prior to addressing the question of the relationship between the dynamics of the Great Western Development and the situation in Xinjiang, it is useful to briefly recall the societal security perspective outlined earlier. As noted above, societal security is brought into question when a society believes that its "we" identity is being put in danger. The threatening of a society’s “we” identity can be compromised through a range of actions, usually state-derived, such as restriction or control of a group's religious, linguistic, and cultural expression or outright suppression. Significantly, Roe suggests that when the "state machinery" is overwhelmingly controlled by the dominant society, "then not only might it be unwilling to provide societal security but may itself be posing the threat” (Roe 2005, 50). How then does the threatened group protect its identity? Waever, notes that in contrast to the classic IR security dilemma that results in arms races/military competition, the "societal security dilemma” results most often in generating non-military means of defence. In such situations, particularly within multi-national states dominated by one major societal unit, the defence of a threatened society's identity will usually result in attempts to strengthen that society's cohesion: 
For threatened societies, one obvious line of defensive response is to strengthen societal identity. This can be done by using cultural means to reinforce societal cohesion and distinctiveness, and to ensure that the society reproduces itself (Waever 1993, 191).

Although this dynamic, as will be outlined below, appears to be operating in the context of Xinjiang, it also needs to be pointed out that this process is not exclusively one way. That is to say, this notion of defending culture "with culture", can be exhibited by both the societal group under threat and the state. As noted above, much of the Chinese state's discourse regarding the Great Western Development, for example, maintains that it is necessary for ensuring national security and development, with the implication that those who oppose or disagree with the thrust of this program are thus threatening state security. This suggests the operation of a somewhat circular dynamic of action-reaction-response on behalf of both the state and societal groups, whereby the implementation of a range of policies in the Great Western Development threaten the societal security of the ethnic minorities, which induces efforts to strengthen societal cohesion that in turn are perceived by the state as jeopardising state security.

Threats to a society's identity can come from many directions, with economic, social and cultural policies of the state all potentially playing a role. In the context of Xinjiang, this is certainly the case. Key elements of this renewed focus on an outright assimilation of the "west" that are well attested in the case of Xinjiang include: increased Han in-migration and settlement; management/control of religious expression; restrictions on the use of minority languages, and political and economic disparities (Becquelin 2000; Mackerras 2001). Another factor that is assuming increased importance in Xinjiang (but also in other regions of the "west") and interacting with those just noted concerns environmental degradation and water scarcity. Indeed, Homer-Dixon asserts that the operation of environmental degradation and water scarcity in combination with such policies as those above can induce "group identity" 
conflicts - that is inter-ethnic conflict (Homer-Dixon 1994). In the context of Xinjiang the response of the threatened society - the Uighur - to this program of state action has been multi-faceted and expressed a far from monolithic or consolidated ethnic identity. The construction of a distinct Uighur identity has been hampered by historical, religious and geographic cleavages and distinctions between the Turkic-speaking oasis dwellers of Xinjiang. More importantly, the (re)emergence of the ethnonym "Uighur" to refer to the Turkic-speaking, Muslim oasis-dwellers of Xinjiang and the evolution of a distinct identity based upon these notions of shared language, history and religion were stimulated by the incorporation of the region into the Chinese state during the first half of the twentieth century:

While the Uyghur have at times in their history been unified for particular sociopolitical purposes, for the most part the people now known by that name were scattered among disparate oases and tribal confederations. Out of opposition to other tribal confederations, and most notably the Chinese state, the people recognized as the Uyghur emerged (Gladney 2004, 209-210).

Given the societal security perspective outlined above, this observation regarding the formation of Uighur identity is instructive in regard to potential implications of the state's actions and discourse in the context of the Great Western Development. The following section will outline the broad contours of the four major aspects of Chinese policy in Xinjiang noted above since the 1990s and suggest that the political, economic and social dynamics generated by them have induced insecurity amongst the Uighur population.

Increased Han in-migration and settlement: The issue of Han in-migration and settlement in Xinjiang is a key factor in generating Uighur perceptions of their "we” identity coming under threat. According to the 2000 census, the Han proportion of Xinjiang's population rose rapidly in the 1990s, with the official population of Han in 1990 standing at 5.69 million, or $37.6 \%$ of the region's population, while by 2000 it had risen to 7.49 million, or 40.6\% of the population (Becquelin 2000; Mackerras 2001, 291-93; Mackerras 2004, 8). Moreover, these figures do not account for the substantial "floating population" of Han in 
Xinjiang, primarily composed of seasonal migrants for the energy and cotton industries in the region, of which the 2000 census estimated there were some 790000 people. Local government's in other provinces have also begun to subsidise the travel costs of such “seasonal” migrations to Xinjiang (Becquelin 2004, 369-70; People’s Daily 200622 August). Thus if this figure was added to the official Han residents of Xinjiang in 2000, the Han population would amount to 8.28 million, an increase of 2.59 million over the 1990-2000 period. Since 1999 (incidentally the beginning of the Great Western Development), the state has also begun a program to incorporate these "sojourners" into the major cities of Xinjiang and grant them access to social services (Becquelin 2004, 369-70). Indeed, the perception that Xinjiang is being "swamped” with Han is often cited, both by external observers and Uighur émigré organisations, as a key concern of the Uighur and as a cause of Uighur opposition and resistance to Chinese rule (Bovingdon 2002, 47-52; Becquelin 2000, 75-77). ${ }^{4}$

Management and control of religious and cultural expression: The post-1949 Chinese state, led by an avowedly Marxist-Leninist party, has always attempted to manage and control the Islamic religious confession of Xinjiang's major ethnic groups through a alternation of "soft" and "hard” policies. In general, the "soft" approach has involved the tolerance, and at times encouragement, of institutionalised Islam (through mosque construction, the Chinese Islamic Association etc) in order to gain the acquiescence of the ethnic minority population. However, this is coupled with parallel "hard" strategies that are implemented when the state perceives that the practice of religion is a "threat" to security. This theme has been particularly evident since the 1990s, with regular campaigns throughout the region to regulate the rate of mosque construction, the re-education and "reform" of imams and greater regulation or closure of madrassahs (Islamic schools). Such cycles of "hard" and "soft" policies toward religion in Xinjiang generally correlate to changing state perceptions of both internal and external threats. The historical precedent has also been continued since 2001, 
with the authorities escalating such monitoring and management of religious institutions immediately after 11 September 2001 (Rudelson \& Jankowiak 2004, 301-02; Amnesty International 2002). As in the past, these measures not only targeted those deemed to be actively opposing the state but were also applied to religious and cultural practices that, in the state's perception, reinforced ethnic minority separateness from the Chinese state. Thus, Muslim clerics and students were arrested or detained for participation in "illegal religious activities," "illegal religious centers" closed, and imams compelled to attend "political education" sessions. Religious worship, education, or instruction has also been restricted to those 18 years of age and above, and a general discrimination against religious observance implemented (Fuller \& Lipman 2004, 333-34; Radio Free Asia 2006).

Policy toward minority languages: The authorities also identify increased censorship of cultural and media circles as a key area of "struggle" in the fight against "separatist" tendencies. The extent of the state's connection of "separatism" with any overt sign of ethnic minority identity has been reinforced since 2001, with the authorities limiting the use of Uighur language in education and the increased censoring of Uighur literature dealing with political or cultural history (Amnesty International 2002; Dillon 2003). Although the use of ethnic minority languages for education is guaranteed under Article 37 of the Law of National Regional Autonomy, and is practiced during primary years of education in classes predominantly comprised of one ethnic minority, standard Chinese is the language of instruction from the senior grades of primary school onward or when the classes are ethnically mixed (Mackerras 2004a, 130). The "paternalist" and “orientalist" view of the ethnic minorities is also extended to the state's perception of the relative worth of minority languages in the context of education, with Xinjiang Party Secretary Wang Lequan stating in 2002 that: 
The languages of the minority nationalities have very small capacities and do not contain many of the expressions in modern science and technology, which makes education in these concepts impossible. This is out of step with the $21^{\text {st }}$ century. That is why the Chinese language is now used as the medium of instruction from the third grade of primary school in Xinjiang, to overcome the language barrier and obstacles to development. This way, the quality of the Uygur youth will not be poorer than that of their Han peers when they grow up.(Wen wei po 20022 August cited in Becquelin 2004, 376).

This clearly carries the implicit notion common in much recent state discourse regarding ethnic minorities noted earlier, that the ethnic minorities are backward and may only "develop" and become "modern” with the assistance of the Chinese state. Moreover, in the post-9/11 environment one scholar has asserted that current state policy toward ethnic minority languages in Xinjiang “implicitly categorizes the Uyghur language as disloyal”, although this may over-state the case somewhat (Dillon 2003). The issue of ethnic minority language in Xinjiang is also complicated by the fact that many Uighurs now view fluency in Chinese language as a prerequisite for higher education and greater employment opportunities (Rudelson \& Jankowiak 2004, 336). Yet, this in itself demonstrates the pressure placed upon ensuring the continuity of a key component of Uighur identity, the Uighur language.

Political and economic disparities: A key factor in the ensuring the political dominance of the Han in Xinjiang, and conversely the political marginalisation of the Uighur, has been the function of China's system of "national regional autonomy". In contrast to the Soviet system whereby its "national minorities” were granted a federal system of national republics with a theoretical right to secession, the CCP permitted the PRC's ethnic minorities a system of limited territorial autonomy. In Xinjiang three levels of “autonomous government” were established between 1952 and 1955: the autonomous region (equivalent to provincial status), autonomous districts and autonomous counties/prefectures. According to the Chinese government's White Paper, Regional Autonomy for Ethnic Minorities in China, autonomous government could be established in a particular locality: (1) when inhabited by one national 
minority, (2) when inhabited by one large national minority including certain areas inhabited by other smaller nationalities and (3) when jointly established by two or more areas each inhabited by a different national minority (Information Office of the State Council 2005). The first designation in the case of Xinjiang is irrelevant, as it is not populated exclusively by one single ethnic minority. The second, however, is applicable to Xinjiang given the multi-ethnic composition of its population. The population of Xinjiang in 1955, the year "regional autonomy" was implemented, has been variously estimated at some four and a half to five million, some seventy to seventy-five per cent of which was accounted for by the Uighur, while the Han accounted for perhaps five per cent. Therefore, in Xinjiang power and representation within the proposed autonomous government was to be divided amongst thirteen constituent ethnic minorities even though the Uighur were evidently in the majority. Moreover, the titular ethnic group in seventeen out of the twenty-seven "autonomous" units established in Xinjiang after 1955 accounted for less than fifty percent of the population of the autonomous unit. The establishment of these "subautonomies" served the major goals of entrenching the idea that Xinjiang belonged to the thirteen officially recognised ethnic groups and of countering the demographic and potential political weight of the Uighur (McMillen 1981, 66-70; Bovingdon 2004). Significantly, although the state's policy on regional autonomy explicitly states that the head of an autonomous region, prefecture or county must be a member of the ethnic group exercising autonomy, in actuality it is the CCP that wields real power in the region. One recent account observed that ethnic minorities are underrepresented in the CCP comprising around 37 per cent of the 958000 party members in Xinjiang (Mackerras 2004b). As such the CCP apparatus in Xinjiang is dominated by Han, a phenomena that is highlighted by the fact that all first Party secretaries across the one hundred and twenty-four prefectural, municipal, and county levels of the Party in Xinjiang, none are from an ethnic minority (Becquelin 2004, 363). Moreover, as a strategic region with a 
substantial ethnic minority population with a history of opposition to Chinese rule, Xinjiang experiences a much higher degree of central government control compared to other provincelevel units. This is reflected in the role of the Han-dominated Production and Construction Corps (PCC) that will be dealt with below, and the September 2002 promotion of Xinjiang's first Party secretary, Wang Lequan, to the Politburo.

The economic development strategy of the state has resulted in the widening of interethnic and regional disparities with in Xinjiang. The vast bulk of central government investment in the region is channelled into infrastructure development, with the government reporting that 70 billion yuan (US\$8.36 billion) had been invested in building highways, power plants and telecommunications by 2003. As Weimer notes, "massive resource transfers” have been directed to Xinjiang since the early 1990s and largely directed to largescale infrastructure or mineral extraction projects that have had a mixed impact on the conditions of the region's ethnic minorities:

Better communication and transport facilities confer genuine and broad benefits yet at the same time facilitate Han in-migration. This in turn provides economic stimulus but gives rise to competition over resources. Construction projects create jobs, yet often these go to Han immigrants rather than local minorities (Weimer 2004, 188).

There is also a continued rural-urban economic disparity, with the annual urban GDP per capita in 2003 standing at 14.3\% (7300 yuan) compared to 8.8\% (1861 yuan) in rural areas. This is significant as the urban populations of Xinjiang are predominantly Han while the rural population remains predominantly ethnic minority (Becquelin 2004, 371; Bachman 2004, 161-173). The economic role of the quasi-military organisation of the Xinjiang Production and Construction Corps (XPCC) also deserves mention as it highlights the state-building imperatives behind the state's economic development strategy. The XPCC serves a dual role as a conduit for Han colonisation and as an instrument of integration. The XPCC has 2.46 million, predominantly Han members, while it operates some 427 industrial and commercial 
enterprises, numerous state farms that occupy a third of the region's arable land, and most of the region's “reform-through-labour” camps, generating $13.2 \%$ of the region's GDP. Furthermore, the XPPC's operation directly under the State Council of the PRC makes it, “vitually independent from the Xinjiang Autonomous Region’s government”, while some $80 \%$ of its budget also comes directly from the central government (Becquelin 2004, 366-70). The XPCC is thus a powerful colonising force through its absorption of Han migrants, securing territory through a string of cities, farm complexes and industries, and ensuring security through its paramilitary functions (Becquelin 2004, 366-70; Seymour \& Anderson 1998; Seymour 2000).

Environmental degradation \& water scarcity: The issues of environmental degradation and water scarcity should also be considered in the context of discussing the societal security of Xinjiang's ethnic minorities. The Chinese government has itself noted that a significant amount of desertification has taken place in Xinjiang as a result of the large-scale process of Han in-migration to the region since 1949, but particularly during the 1990s. In particular, it has been noted that some $300 \mathrm{~km}$ of the Tarim River and its tributaries (in southern Xinjiang) has entirely dried up since the 1970s as the result of urbanization, extensive irrigation and land reclamation projects. The state's response has been to embark upon a "rehabilitation" program for the Tarim River by diverting water from northern Xinjiang to the south in order to "restore water to $240 \mathrm{~km}$ of the dried up river bed" (Becquelin 2004, 366; People’s Daily 200120 January; Radio Free Asia 2006). Whether projects such as these can halt the depletion of Xinjiang's water resources is questionable given that only $4.3 \%$ of the region's land is arable and Xinjiang's population density remains high at 249 per square kilometre (South China Morning Post 200219 July; Blua 2004). Continued depletion of the region's water resources and desertification could thus contribute to further pressures on the ethnic minority population of Xinjiang. Finally, Xinjiang is also 
home to some of China's most important nuclear facilities, including the testing ground in the Lop Nor desert. The environmental impact of China's nuclear tests, have also been a cause of grievance for the region's ethnic minorities. In particular the late 1980s and early 1990s saw a number of protests against the continued operation of China's nuclear facilities at Lop Nor (Dillon 1995: 19; East Turkistan Information Bulletin 1993).

As we have seen China's approach to Xinjiang is thus defined by a dual strategy of rapid economic modernisation and development, and a zero-tolerance approach to expressions of autonomy or secession. Indeed, a further indication of the logic or rationale driving the Great Western Development in the context of ethnic minority regions can be seen, for example, in the comments of Tondrub Wangden, Vice-Director of the State Ethnic Affairs Commission that:

China's policy is by no means cultural assimilation. It focuses more on cultural development...Preservation does not mean isolation. While we are protecting cultural heritage, we need to think of the problem of development (People's Daily 200622 September. My emphasis).

In the state's perception, and implied in the above comment, "protection" of ethnic minority cultural "heritage" can only be achieved through further modernisation, and therefore further integration with the Chinese state. The progress of Chinese policy in Xinjiang since the initiation of the Great Western Development has certainly reflected this notion of the Chinese state as the agent of modernisation. As we have seen, the program of development in Xinjiang has been underpinned by such strategies as rapid Han in-migration and zero-tolerance for expressions of ethnic minority autonomy that can be seen to contribute to societal insecurity amongst the non-Han population of the region. An increasingly important element in this latter respect in the post-9/11 international environment has been the Chinese state's categorisation of violent incidents of Uighur opposition to Chinese rule as "terrorism". 


\section{The Discourse of Uighur "Terrorism": An External Manifestation of the Great Western Development?}

Although much Uighur opposition to Chinese rule is non-violent and often takes the form of passive, “everyday resistance”, it is important to examine the Chinese government's discourse regarding Uighur "terrorism” in Xinjiang because, as I shall suggest below, it serves as a supportive pillar both domestically and internationally for its program of development in the region (Bovingdon 2002, 45-53; Smith 2002). As noted earlier, Xinjiang has a relatively recent history of separation from and conflict with the Chinese state in the form of the two East Turkestan Republics proclaimed in 1933 and 1944. In the contemporary post-9/11 context the nature of these two independence movements - particularly the relationship between the separatists and external influence from Central Asia, and the role of Islam weigh especially heavy on Chinese perceptions of the causes and potential outcomes of such movements. Thus it is interesting to note the current Chinese government's account of the pre-1949 Uighur separatist movements. Instructively, the most germane aspects of the two short-lived republics in the recent Chinese "White Paper on the History and Development of Xinjiang” was the perceived connection between the separatist demands of Uighurs, external forces and radical religious and nationalist ideologies. The view that such past, and by implication current and future, separatism in Xinjiang was generated by a combination of malevolent external forces and radical Islamist or nationalist ideologies is clearly expressed:

In the early twentieth century, and later, a small number of separatists and religious extremists in Xinjiang, influenced by the international trend of religious extremism and national chauvinism, politicized the unstandardized geographical term "East Turkistan", and fabricated an "ideological and theoretical system" on the so-called "independence of East Turkistan"...They incited all ethnic groups speaking Turki and believing in Islam to join hands to create a theocratic state. They denied the history of the great motherland jointly built by all ethnic groups of China. They clamored for "opposition to all ethnic groups other than the Turks" and for the "annihilation of pagans", asserting that "China had been the 
enemy of the 'East Turkistan' nation for 3000 years” (Information Office of the State Council 2003. My emphasis.)

This account of the development of Uighur separatism in Xinjiang also very clearly projects into the past the Chinese state's contemporary concerns and fears regarding Uighur separatism in the region. This discourse not only presents China's security concerns in Xinjiang as part of the wider international "War on Terror", but also elucidates it in a particularly strident manner to convey the "clear and present" danger of Uighur "terrorism" to China’s national security.

As noted earlier, "securitisation theory" argues that security issues are constructed “according to a dialectic between securitizing state agents and an accepting or rejecting public audience, mediated by a stock discourse of security characteristics such as urgency and exceptionality” (Neal 2006, 34). In the case of Xinjiang, it is difficult to establish explicitly whether the public audience is "accepting or rejecting" of this discourse, but as alluded to by the examples above (and outlined below) the state could be seen as embarking upon such a project. The report cited above claims that since 1990 Xinjiang has witnessed "over 200 terrorist incidents” including explosions, assassinations, attacks on police and government institutions, crimes of poison and arson, establishment of secret training bases and plotting and organising disturbances. Moreover, these attacks are claimed to have resulted in the deaths and injury of one hundred and sixty-two and four hundred and forty people respectively. The document also identifies a number of "East Turkistan terrorist forces”, such as the "Uighur Liberation Organisation" (ULO) and the "East Turkistan Islamic Movement" (ETIM), which it claims were responsible for these incidents. James Millward has demonstrated, however, in his detailed examination of violent separatism in Xinjiang that the Chinese government's account is far from systematic or consistent. For example, from the data supplied in the Chinese document the total number of deaths directly attributed to “terrorism” in Xinjiang between 1990 and 2001 is fifty-seven, while the number injured is 
three hundred and sixty-two, substantially less than the figures of one hundred and sixty-two and four hundred and forty people killed and injured stated in the introduction to the report. Moreover, most of the deaths and injuries for which evidence is provided occurred as a result of small-scale incidents with only one or two victims (Millward 2004, 12-22; Information Office of the State Council of the PRC 2002).

A crucial element of these claims, however, in the context of the post-9/11 international environment and one that highlights the "securutization" of Uighur separatism, is the claim that Uighur "separatists" or "terrorists" are intimately connected to Osama bin Laden's alQaeda network and related movements in Afghanistan and the post-Soviet Central Asian states. The Chinese government report cited above clearly links violent incidents in Xinjiang to bin Laden and other Central Asian Islamist groups:

The "East Turkistan Islamic Movement" headed by Hasan Mahsum is supported and directed by bin Laden. Since the formation of the "East Turkistan Islamic Movement", bin Laden has schemed with the heads of the Central and West Asian terrorist organizations many times to help the "East Turkistan" terrorist forces in Xinjiang launch a "holy war", with the aim of setting up a theocratic "Islam state" in Xinjiang (Information Office of the State Council of the PRC 2002).

The report then claims that ETIM's leader, Hasan Mahsum, met bin Laden in Afghanistan in 1999 and 2001 in order to receive training and material aid, and to coordinate ETIM's operations with those of al Qaeda, the Taliban and the Islamic Movement of Uzbekistan (IMU). Indeed, this discourse can be said to have succeeded to an extent internationally with the US State Department listing ETIM as an international terrorist organisation in September 2002 (Fuller \& Lipman 2004, 342-43). Since 2002 there has continued to be numerous press articles in the Chinese media concerning the subjects of the international "War on Terror" and “terrorism” in Xinjiang and Central Asia that consistently elucidate the position that separatist forces in Xinjiang are intimately connected to al Qaeda, the Taliban and the IMU. China has also vigorously sought the return of twenty Uighurs held in the US military's detention 
facility at Guantanomo Bay, Cuba, who had been apprehended in Afghanistan and Pakistan following the post-9/11 US military action in Afghanistan (China Daily 200226 January; Xin 2004; People’s Daily 200318 December; Forney 2002, 38-39). China’s ire was raised considerably in August 2004 when then US Secretary of State Colin Powell stated that the US would not return the Uighurs, if released, to China. The issue of the repatriation of the Guantanomo Uighurs resurfaced early in 2006, when the US government released five Uighurs, who were subsequently offered asylum by Albania on May 6, 2006 (Wu 2005; BBC News 2006). Continuing the portrayal of Uighur opposition as linked to the "War on Terror", the Chinese ambassador to Albania responded to this development by asserting that the five Uighurs had, "fought on the side of the Taliban during the Afghan War, and this fact alone proves that they are nothing but terrorist suspects” (China Daily 20065 May). ${ }^{6}$

The Chinese state's discourse regarding Uighur "terrorism" in Xinjiang that has emerged since 2001 obviously has an important international dimension, particularly in the context of China's relations with the US and the Central Asian republics. With respect to relations with the latter, China has striven since 2001 to achieve the cooperation of the Central Asian states, both individually through bilateral agreements and collectively through the mechanism of the Shanghai Cooperation Organisation (SCO), in its endeavour to counter Uighur separatist tendencies within the region. In this regard it has succeeded in the context of both the SCO and bilateral relations, with the former undertaking a number of joint military exercises with a strong anti-terrorism focus in 2003 and establishing a "Regional AntiTerrorism” unit in Tashkent in 2004. Bilaterally, China has been successful in gaining the cooperation of the Central Asian states, but particularly Kazakhstan and Kyrgyzstan, in not only in acknowledging China's security concerns in Xinjiang but also in apprehending and extraditing suspected Uighur separatists and “terrorists” back to China, and clamping down upon the activism of the significant populations of Uighurs residing in these states. 
Significantly, the various SCO meetings since 2001 have also been explicit in identifying one of the major goals of the organisation to be to combat the "three evils of extremism, terrorism and separatism” (Chung 2004, 990-91; Swanstrom 2005; Ong 2005, 429-431; Tarimi 2004). In this regard Michael Dillon has noted that China, "By defining all separatist activity in Xinjiang as terrorist, the government of the PRC is hoping to obtain carte blanche from the international community to take whatever action it sees fit in the region” (Dillon 2004, 162). This process also has an important domestic counter-point that is hinted at by the policies and discourse of the state's program of integration and development in Xinjiang that were examined earlier - the Chinese state's move beyond a multi-national "patriotism” towards a more consolidated, and perhaps confident, Chinese nationalism. As we have seen, perhaps those to bear the full brunt of the Chinese state's vigour will be its ethnic minority populations, particularly those such as the Uighur who are strategically located and have a history of opposition and separateness from China.

This paper, in exploring the applicability of notions of human security to China's evolving approach toward its multi-ethnic population, proposed three major questions in the specific context of Xinjiang. First, which collectivity is the state acting to protect? Second, how do the actions taken to protect the security of the state impact upon the societal security of the constituent populations of the state? Third, does the Chinese state's actions and discourse exhibit a "securitization” dynamic whereby key issues are deemed to be defined by “urgency” and “exceptionality”? As outlined above, the discourse surrounding the state's “Great Western Development” strategy, suggests that while the state continues to stress the need to address the problems of uneven development in ethnic minority regions, it nonetheless maintains that this will be done on the basis of preserving "national unity" and "social stability" with the dominant ethnic group - the Han - as the leading agents of modernization. Meanwhile, the discussion of the contours of state policy in Xinjiang over the 
1991 to 2006 period demonstrated that elements and side-effects of the state's development strategy - such as Han in-migration and environmental degradation - can be seen to have exacerbated inter-ethnic relations in the region. Moreover, the societal security perspective suggested that when a society perceives that it's “we” identity may be under threat, it will usually result in attempts to strengthen societal cohesion through revitalisation of aspects of collective identity such as language and religion. In the case of the Uighur, the paper highlighted the state's ongoing concern to manage and control the practice of aspects of Uighur identity, such as religious observance, which have experienced a revival since 1991. The discussion also highlighted that such processes of increased state control in these spheres have also developed simultaneously with further marginalisation of Xinjiang's ethnic minorities, but particularly the Uighur, from avenues of political representation and economic advancement. Finally, the discussion of the discourse surrounding the issue of Uighur "terrorism” in the post-9/11 context also noted the interaction between elements of China's strategy of integration and control and its foreign policy agenda with respect to the Central Asian republics. Indeed, as noted above, the "securitization" of Uighur terrorism through the deployment of a consistent state-discourse regarding alleged connections between Uighur organisations and "international terrorism" has been successful for China, particularly in its relations neighbouring Kazakhstan and Kyrgyzstan. However, it is also clear from the preceding discussion that in spite of some correlations between societal security theory and developments within Xinjiang over the 1991-2006 period the Uighur response to threats to its "we" identity cannot be said at this juncture to constitute a genuine challenge to the state. This suggests that further theoretical development of the concept of societal security and further exploration of the interaction between ethnic identities and the Chinese state's modernization project are required in order to "flesh out" the initial picture of the relationship between identity and security in Xinjiang presented here. 


\section{NOTES}

${ }^{1}$ The author would like to thank members of the Griffith Asia Institute's "China Policy Project" for their comments and suggestions on an earlier draft of this paper, and Mr. Liu Xian for his translation of Chinese sources.

${ }^{2}$ Xinjiang, in the far north-west of China, is China's largest administrative unit, accounts for one sixth of its total territory, shares borders with Pakistan, Afghanistan, Tajikistan, Kyrgyzstan, Kazakhstan, Russia and Mongolia and is populated by thirteen, predominantly Turkic-Muslim ethnic groups. The thirteen officially recognised ethnic groups of Xinjiang are: Uighur, Kazakh, Kyrgyz, Tajik, Uzbek, Hui, Mongol, Tartar, Russian, Solon, Xibo, Manchu, and Han.

${ }^{3}$ There are fifty-six officially recognised ethnic groups or minzu in China, including the majority Han (Mackerras 2004a)

${ }^{4}$ Between 1911 and 1949 Xinjiang was dominated by independent Han "warlords" and experienced major Soviet influence. However, the Uighur and other ethnic groups established two nascent independent states - the Turkish Islamic Republic of East Turkestan (TIRET) in 1933-34 and the East Turkestan Republic (ETR) in 1944-49 (Forbes 1986; Wang 1999).

${ }^{5}$ The issue of population transfers to ethnic minority regions has been particularly evident in ongoing controversies regarding Chinese policy towards Tibet, although recent research suggests that such claims have been over-stated by Tibetan exile organisations (Suatman 2006). In the context of Xinjiang, the claim that the Uighur and other ethnic groups were being diluted by Han in-migration has also been evident for some decades. Although in Xinjiang the dynamic of Han in-migration to the region has undergone fluctuations, generally correlated to changing state policy. For example, the Han proportion of the population actually fell during the 1980 s, from $40.45 \%$ in 1982 to $37.58 \%$ in 1990 , with the relaxation of the coercive population transfers of the Maoist period. This figure then rose substantially to $40.6 \%$ in 2000 as the state's program of economic reform and development encouraged Han in-migration (Mackerras 2001; Becquelin 2004).

${ }^{6}$ For an account of the fate of the Uighurs released from Guatanomo Bay, and their alleged connections to Osama bin Laden and Afghanistan see (Cloud \& Johnson 2004).

\section{REFERENCES}

Amnesty International. 2002. People's Republic of China: China's Anti-Terrorism Legislation and Repression in the Xinjiang Uighur Autonomous Region, March 22. [accessed August 12, 2002], <http://web.amnesty.org/library/index/ENGASA170102002>

Bachman, David. 2004. Making Xinjiang Safe for the Han? Contradictions and Ironies of Chinese Governance in China's Northwest, in Governing China's Multiethnic Frontiers, ed. Morris Rossabi: 155-185. Seattle: Washington University Press.

BBC News. 2006. Albania Takes Guantanomo Uighurs. May 6 [accessed September 22, 2006], <http://newsvote.bbc.co.uk> 
Becquelin, Nicolas. 2000. Xinjiang in the Nineties, The China Journal 44, (July): 65-90

Becquelin, Nicolas. 2004. Staged Development in Xinjiang, China Quarterly 178, (June): 358-378.

Blua, Antoine. 2004. China's Mounting Influence - Xinjiang's Thirst Threatens Kazakh Water Resources. Eurasianet, November 24. [accessed December 10, 2004] $<$ http://www.eurasianet.org $>$.

Bovingdon, Gardner. 2002. The Not-So-Silent Majority: Uyghur Resistance to Han Rule in Xinjiang. Modern China 28: 1, (January): 39-78.

Bovingdon, Gardner. 2004. Heteronomy and Its Discontents: 'Minzu Regional Autonomy' in Xinjiang, in Governing China’s Multiethnic Frontiers, ed. Morris Rossabi: 118-149. Seattle: University of Washington Press.

Buzan, Barry. 1991. People, States and Fear: An Agenda for International Security Studies in the Post-Cold War Era. London: Harvester Wheatsheaf.

China Daily. 2002. Islamic Community Condemns 'East Turkistan' Terrorist Forces. January 26. [accessed October 5, 2004], <http://www.chinadaily.com.cn/en/doc/2002$\underline{01 / 26 \text { ?content_103990.htm> }}$

China Daily. 2006. China Demands Return of Guantanomo Detainees. May 5 [accessed September 22, 2006], <http://www.chinadaily.com.cn/china/2006-05/10/content_586168.htm>

Chung, Chien-peng. 2004. The Shanghai Cooperation Organization: China's Changing Influence in Central Asia. The China Quarterly 180, (December): 989-1009.

Cloud, David S. and Ian Johnson. 2004. Friend or Foe: In the Post 9/11 World, Chinese Dissidents Pose US Dilemma. Wall Street Journal (Eastern edition). August 3.

Dillon, Michael. 1995. Xinjiang: Ethnicity, Separatism and Control in Chinese Central Asia. University of Durham: Durham East Asian Papers 1.

Dillon, Michael. 2003. Uyghur Language and Culture Under Threat in Xinjiang. Central Asia-Caucasus Analyst, August 14, [accessed March 28, 2003], $<$ http://www.cacianalyst.org/view_article.php?articleid=23 $>$

Dillon, Michael. 2004. Xinjiang: China's Muslim Far Northwest. New York: RoutledgeCurzon.

East Turkestan Information Bulletin. 1993. Nuclear Test Site Attacked 3: 3, (June). [accessed June 20, 2001], http://www.taklamakan.org

Forbes, Andrew D. W. 1986. Warlords and Muslims: A Political History of Republican Sinkiang, 1912-1949. Oxford: Oxford University Press.

Forney, Matthew. 2002. One Nation Divided: Since September 11, Beijing Has Been Cracking down in Xinjiang. Time, March 25: 38-39. 
Fuller, Graham E. \& Jonathan Lipman. 2004. Islam in Xinjiang in Xinjiang: China's Muslim Borderland, ed. S. Frederick Starr: 320-352. Armonk, NY: M. E. Sharpe.

Gladney, Dru C. 2004. Dislocating China: Muslims, Minorities and Other Subaltern Subjects. London: Hurst \& Company.

Goodman, David S. 2004. The Campaign to 'Open Up the West': National, Provincial-level and Local Perspectives. China Quarterly 178, (June): 317-334.

Holbig, Heike. 2004, The Emergence of the Campaign to Open Up the West: Ideological Formation, Central Decision-making and the Role of the Provinces, China Quarterly 178, (June): 335-357.

Homer-Dixon, Thomas. 1994. Environmental Scarcities and Violent Conflict: Evidence from Cases. International Security 19: 1, (Summer): 5-40.

Information Office of the State Council of the PRC, "East Turkistan Terrorist Forces Cannot Get Away with Impunity.” People's Daily, 21 January 2002.

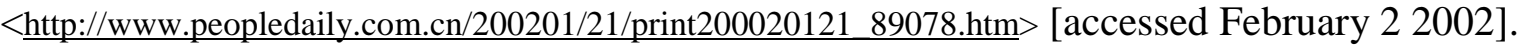

Information Office of the State Council. 2003. White Paper on the History and Development

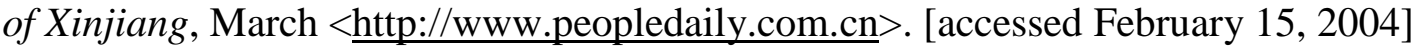

Information Office of the State Council of the PRC. 2006. Regional Autonomy for Ethnic Minorities in China, February 2005, [accessed September 27, 2006], $<$ http://english.gov.cn/official/2005-07/28/content_18127.htm>.

Li Dezhu. 2000. Xibu Da Kaifa yu Minzu Wenti [Large-scale Development of Western China and China's nationality problem]. Qiushi [Seeking Truth] 1 June in FBIS-CHI-2000-0601, 2 June 2000.

Mackerras, Colin. 2001. Xinjiang at the Turn of the Century: the Causes of Separatism. Central Asian Survey 20: 3: 289-303.

Mackerras, Colin. 2004a. China's Ethnic Minorities and Globalisation. London: RoutledgeCurzon.

Mackerras, Colin. 2004b. Ethnicity in China: The Case of Xinjiang. Harvard Asia Quarterly 8: 1, (Winter): 4-14.

Mackerras, Colin. 2006. Why Terrorism Bypasses China's West. Asia Times, April 23. [accessed September 29, 2006], <http://www.atimes.com>

Mao Zedong. 1986. On the Ten Great Relationships, (25 April 1956) in The Writings of Mao Zedong, 1949-1976: Vol. II, January 1956-December 1957 ed. Michael Y. M. Kau and John K. Leung: 43-66. Armonk, NY: M. E. Sharpe.

McMillen, Donald H. 1981. Xinjiang and the Production and Construction Corps: A Han Organization in a Non-Han Region, Australian Journal of Chinese Affairs 6: 65-96. 
Millward, James A. 2004. Violent Separatism in Xinjiang: A Critical Assessment, Policy Studies 6. Washington, D.C.: East-West Center.

Neal, Andrew W. 2006. Foucault in Guantanamo: Towards an Archaeology of Exception. Security Dialogue 37: 1, (March): 31-46.

Ong, Russell. 2005. China’s Security Interests in Central Asia. Central Asian Survey 24: 4, (December): 425-439.

People's Daily. 2001. Xinjiang to revive Lop Nor by water diversion. January 20. [accessed April 23, 2001], <http://www.peopledaily.com.cn>

People's Daily. 2003. Combating Terrorism, We Have No Choice. December 18 [accessed February 13, 2004], <http://www.peopledaily.com.cn>

People’s Daily. 2006. SW China farmers leave for border region for 'cotton exodus'. August 22. [accessed August 26, 2006], < $\underline{\text { http://www.peopledaily.com.cn }>}$

People’s Daily. 2006. Great Efforts made to Prevent Cultural Assimilation: Chinese Official. $\begin{array}{lllll}\text { September } 22 . & \text { [accessed } & \text { September }\end{array}$ $<\underline{\text { http://english.people.cn/200609/22/print20060922_305093.html }>}$

Radio Free Asia. 2006. China Bans Officials, State Employees, Children from Mosques. February 6. [accessed September 29, 2006], < http://www.rfa.org/english/news/2006/02/06/uyghur_religion/>

Radio Free Asia. 2006. China Moves Farmers as Tarim River Waters Dwindle. April 3. [accessed September 29, 2006], http://www.rfa.org/english/uyghur/2006/04/03/uyghur_tarimriver/

Roe, Paul. 2005. Ethnic Violence and the Societal Security Dilemma. London: Routledge.

Rudelson, Justin and William Jankowiak. 2004. Acculturation and Resistance: Xinjiang Identities in Flux in Xinjiang: China's Muslim Borderland, ed. S. Frederick Starr: 299-319. Armonk, NY: M. E. Sharpe.

Sautman, Barry. 2006. Colonialism, Genocide and Tibet. Asian Ethnicity 7: 3 (October): 243265.

Seymour, James D. and Richard Anderson. 1998. New Ghosts, Old Ghosts: Prison and Labor Reform Camps in China. Armonk, NY: M. E. Sharpe.

Seymour, James. 2000. Xinjiang's Production and Construction Corps, and the Sinification of East Turkestan. Inner Asia 2: 2:171-193.

Sines, Abigail. 2002. Civilizing the Middle Kingdom's Wild West, Central Asian Survey 21: 1: 5-18.

Smith, Joanne N. 2002. 'Making Culture Matter': Symbolic, Spatial and Social Boundaries between Uyghurs and Han Chinese. Asian Ethnicity 13: 2, (September): 153-174. 
South China Morning Post. 2002. Traffic flows where river once did. July 19. [accessed July 30, 2002], <http://www.scmp.com>

Swanstrom, Niklas. 2005. China and Central Asia: A New Great Game or Traditional Vassal Relations? Journal of Contemporary China 14, (November): 569-584

Tarimi, N. T. 2004. China-Uzbek Pact Bad News for Uighurs. Asia Times, July 30 [accessed September 25, 2006], <http://www.atimes.com>

Tyler, Christian. 2003. Wild West China: The Untold Story of a Frontier Land. London: John Murray.

Waever, O, B. Buzan M. Kelstrup and P. Lemaitre. 1993. Identity, Migration and the New Security Agenda in Europe, London: Pinter.

Wang, David D. 1999. Under the Soviet Shadow: The Yining Incident. Ethnic Conflicts and International Rivalry in Xinjiang, 1944-1949. Hong Kong: Chinese University Press.

Weimer, Calla. 2004. The Economy of Xinjiang in Xinjiang: China's Muslim Borderland, ed. S. Frederick Starr: 163-189. Armonk, NY: M. E. Sharpe.

Wen wei po (Hong Kong). 2002. 2 August in FBIS-CHI-2002-0307, 3 August 2002. Cited in Becquelin, Nicolas. 2004. Staged Development in Xinjiang, China Quarterly 178, (June): 376.

Wu Yixue. 2004. When is a Terrorist not a Terrorist? August 19 [accessed April 20, 2005], <http://www.chinadaily.com.cn/english/doc/2004-08/19/content_366847.htm>

Xin Dingding. 2003. Terror List with Links to al-Qaida Unveiled. China Daily HK Edition, December 12 [accessed October 5, 2004], <http://www.chinadaily.com.cn/en/doc/hk>

Zhu, Yuchao and Dongyan Blachford. 2006. China's Fate as a Multinational State: A Preliminary Assessment. Journal of Contemporary China 15, (May): 329-348. 